NBER WORKING PAPER SERIES

\title{
SIMULATING THE DYNAMIC MACROECONOMIC AND MICROECONOMIC EFFECTS OF THE FAIRTAX
}

\author{
Sabine Jokisch \\ Laurence J. Kotlikoff \\ Working Paper 11858 \\ http://www.nber.org/papers/w11858 \\ NATIONAL BUREAU OF ECONOMIC RESEARCH \\ 1050 Massachusetts Avenue \\ Cambridge, MA 02138 \\ December 2005
}

Part of this paper draws directly from Fehr, Jokisch, and Kotlikoff (2005b). We thank FairTax.org for support. The views expressed herein are those of the author(s) and do not necessarily reflect the views of the National Bureau of Economic Research.

(C)2005 by Sabine Jokisch and Laurence J. Kotlikoff. All rights reserved. Short sections of text, not to exceed two paragraphs, may be quoted without explicit permission provided that full credit, including () notice, is given to the source. 
Simulating the Dynamic Macroeconomic and Microeconomic Effects of the FairTax Sabine Jokisch and Laurence J. Kotlikoff

NBER Working Paper No. 11858

December 2005

JEL No. H2

\begin{abstract}
America's aging coupled with high and growing old age health and pension benefits augers for much higher payroll taxes, with potentially damaging effects on the U.S. economy. This prognosis is supported by our analysis of a detailed dynamic life-cycle general equilibrium model, which closely captures projected changes in U.S. demographics. The FairTax offers a potential alternative to this dismal economic future. The FairTax proposes to replace the federal payroll tax, personal income tax, corporate income tax, and estate tax (not modeled here) with a progressive consumption tax delivered in the form of a federal retail sales tax plus a rebate.
\end{abstract}

According to our simulation model, these policy changes would almost double the U.S. capital stock by the end of the century and raise long-run real wages by 19 percent compared to the base case alternative. They would also preclude a doubling of the highly regressive payroll tax. Indeed, the poorest members of each cohort experience remarkably large welfare gains from the FairTax. To be specific, today's elderly poor are predicted to experience a 13 to 14 percent welfare gain. In contrast, their middle class counterparts enjoy a 1 to 2 percent gain, and their richest counterparts experience a .5 to 1 percent welfare loss. Poor baby boomers experience 8 percent gains, while middle- and upper-income boomers experience either very small welfare losses or small gains.

Once one moves to generations postdating the baby boomers there are positive welfare gains for all income groups in each cohorts. For example, the poorest members of the generation born in 1990 enjoy a 16 percent welfare gain. Their middle-class and rich contemporaries experience 5 and 2 percent welfare gains, respectively. The welfare gains are largest for future generations. Take the cohort born in 2030. The poorest members of this cohort enjoy a huge 27 percent improvement in their well being. For middle class members of this birth group, there's an 11 percent welfare gain. And for the richest members of the group, the gain is 5 percent. The remarkable point here is the size of the gains from the reform relative to the losses. Yes, some initial high- and middle-income households are made worse off, but their welfare losses are minor compared with the gains available to future generations, particularly the poorest members of future generations.

While our model is highly stylized, it suggests that the FairTax offers a real opportunity to improve the U.S. economy's performance and the wellbeing of the vast majority of Americans. The winners from this reform, primarily those who are least well off, experience very major gains, and the losers experience only minor losses.

Sabine Jokisch

Centre for European Economic Research

Mannheim

GERMANY

jokisch@zew.de
Laurence J. Kotlikoff

Department of Economics

Boston University

270 Bay State Road

Boston, MA 02215

and NBER

kotlikof@bu.edu 


\section{Introduction}

This paper uses a life-cycle, general equilibrium model developed in Fehr, Jokisch, and Kotlikoff $(2003,2004 a, 2004 b, 2005 a$, and 2005b) to study the dynamic macroeconomic and microeconomic effects of replacing all federal taxes with a progressive, broad based consumption tax,namely the FairTax. The FairTax combines a federal retail sales tax, levied at a single rate, with a rebate the size of which depends on the household's characteristics. Businesses purchases would be exempt from the FairTax on their purchases, since such purchases do not represent consumption. The FairTax also increases Social Security benefits to maintain their real purchasing power. Finally, the FairTax reduces non-Social Security federal expenditures to help pay for its introduction of a major new transfer (equivalently, tax expenditure), namely the FairTax rebate.

As specified in HR25, the legislation that would implement the FairTax, the FairTax would be levied at a 30 percent nominal rate and a 23 percent effective rate. The nominal rate refers to the rate one would pay at the store in purchasing a good or service. To see the relationship between the nominal and effective rates, consider spending 1 dollar at a retail store. With a 30 percent sales tax rate, one ends up with only 77 cents in actual consumption since 23 cents (which is 30 percent of 77 cents) goes to taxes. So paying a 30 percent retail sales tax when one spends one's income or wealth is the same as facing no retail sales tax, but having one's income and wealth reduced by 23 percent.

Households finance current and future consumption with their current wealth and their current and future labor earnings. Taxing consumption expenditures is, thus, effectively equivalent to taxing what is used to pay for consumption, namely existing wealth as well as today's and tomorrow's labor income. In the case of the FairTax, every dollar of existing wealth as well as every dollar of current and future earnings would be effectively taxed at a 23 percent rate.

Under the current U.S. federal tax system, total effective marginal tax rates on labor supply are higher than 23 percent for almost all American households. Indeed, as shown in Kotlikoff (2005), typical middle-aged and middle-income earners face total effective federal marginal tax rates on working of roughly 30 percent. For these and most other households, the FairTax would dramatically improve labor supply incentives. 
Since the FairTax taxes consumption at the same rate no matter when it occurs, it imparts no incentive to consume now as opposed to later and, thus, no disincentive to save. In economic terms, the FairTax's marginal effective tax rate on saving is zero. In contrast, the existing federal tax system imposes very high marginal effective tax rates on saving. This point is also documented in Kotlikoff (2005), who reports marginal taxes on saving for stylized households ranging from 20 percent to 54 percent.

In addition to imposing, in almost all cases, much lower marginal taxes on working and, in all cases, dramatically lower marginal taxes on saving, the FairTax imposes lower average taxes on low- and middle-income working households than does the current system. It does so, in part, by broadening the tax base from what is now primarily labor income to the sum of labor income and current wealth and, in part, by reducing non-Social Security real federal expenditures to help pay for the FairTax rebate. In particular, the reform implies a real reduction in federal purchases of goods and services, which many Americans many view as desirable. In this regard, it should be noted that federal purchases of goods and services, measured as a share of GDP, have. risen by over one fifth since 2000 .

Would switching to the FairTax enhance or undermine progressivity? The implicit taxation of wealth under the FairTax is certainly a highly progressive element of the proposed reform. So too is the elimination of the highly regressive payroll (FICA) tax and the implementation of the FairTax's highly progessive rebate. On the other hand, the personal income tax is progressive, albeit less progressive than many seem to believe (see Gokhale, Kotlikoff, and Sluchynsky, 2003). Understanding the FairTax's net impact on progressivity is one of this study's goals. What about the FairTax's treatment of the elderly? Well, HR25 would increase Social Security benefits by 30 percent to maintain the purchasing power of those transfer payments. In addition, it provides the rebate to all American households, including the elderly. In so doing, it overcompensates the poor elderly who live either entirely or primarily off of Social Security; i.e., the poor elderly receive the rebate even though the purchasing power of their Social Security benefits remains unchanged.

In contrast to the poor elderly, the middle class and rich elderly finance much or most of their consumption from their accumulated wealth. The purchasing power of this wealth is reduced 
by the FairTax. Hence, the FairTax imposes a higher fiscal burden on the middle class elderly and the rich elderly than does the existing tax structure. In the life-cycle model, the elderly have a higher propensity to consume out of their remaining lifetime resources than do young and certainly future generations. Hence, shifting the burden of taxation from young and future generations to initial older generations reduces aggregate private consumption and increases national investment. Increased investment means, in turn, more capital per worker and, thus, higher labor productivity and real wages.

In the simulations presented below, the shift to the FairTax raises marginal labor productivity and real wages, over the course of the century, by 18.9 percent and long-run output by 10.6 percent. Moreover, the FairTax reduces by half the long-run increase in the effective rate of wage taxation needed to pay the Social Security and healthcare benefits of an aged country.

These macroeconomic gains have important microeconomic welfare implications. In the long run, low-income households experience a 26.7 percent welfare gain, middle-income households experience a 10.9 percent welfare gain, and high-income households experience a 4.7 percent welfare gain. This is a very progressive long-run outcome. But progressivity marks the entire transition. Low income households who are initially alive at the time of the reform, whether they are young, middle age, or old, all experience welfare gains ranging from 8.3 percent to over 20 percent. Who pays for these substantial welfare gains? The answer is hardly anyone. The initial rich elderly and middle aged as well as some middle age middle-income households are made worse off, but their welfare losses are quite small compared to the welfare gains experienced by the current poor and future generations. One reason the FairTax offers such significant welfare improvements for winners and such small losses for losers is that it significantly improves economic incentives, particularly the incentive to save, and, thereby, reduces economic distortions; i.e., excess burden.

The model generating the above-mentioned results treats the U.S. economy as closed, which in this context means its domestic investment is determined by its own saving. As shown by Feldstein and Horioka (1980), there is much truth to this proposition. But for sake of completeness, we also consider the other extreme assumption, namely that U.S. domestic investment is fully determined by international capital flows; i.e., we also run the model treating the U.S. as a small 
open economy. Our small open economy results are not quite as dramatic as our close economy findings. But the potential economic gains remains impressive and run in the same direction. In this case the shift to the FairTax raises the long-run (year 2100) capital stock by 40.4 percent and long-run real wages by 11.1 percent. In the long run, low-income households experience a 23.1 percent welfare gain, middle-income households experience a 9.0 percent welfare gain, and high-income households experience a 4.7 percent welfare gain.

\section{Our Model and Its Predecessors}

The usefulness of our findings depends, of course, on the realism of our model. Our model includes age- and year-specific fertility and mortality rates, lifespan uncertainty, age- and yearspecific pension, disability, health care, and other government transfer policies, year-specific government purchases of goods and services, government debt, high, middle, and low earners within each cohort in each region, personal income taxes, corporate income taxes, and payroll taxes,technological change, age-specific inheritances, age-specific and unintended bequests, intertemporally separable CES utility functions in consumption and leisure, region-specific CobbDouglas production functions, the presence of children's utility in parents' utility functions when the children are young, exogenously specified age-, earnings class-, region-, and year-specific immigration, and region- and cohort-specific time preference rates.

The development of dynamic life-cycle simulation models was stimulated by Feldstein's (1974) article contending that government pension systems lower national saving. Early dynamic analysis of government pension programs and other policies include Kotlikoff (1979), Summers (1981), Auerbach and Kotlikoff $(1983,1987)$, and Seidman (1986). More recent papers have considered the importance of land, earnings uncertainty, political economy considerations, liquidity constraints, different options for funding Social Security, and human capital decisions. These studies include Hubbard and Judd (1987), Imrohoroglu, Imrohoroglu, and Joines (1995, 1999), Kotlikoff (1996), Huang, Imrohoroglu, and Sargent (1997), Huggett and Ventura (1998), Cooley and Soares (1999a, 1999b), De Nardi, Imrohoroglu, and Sargent (1999), Kotlikoff, Smetters and Walliser (1998a, 1998b, 1999, and 2002), Raffelhüschen (1989, 1993), Heckman, Lochner, and

Taber (1998), Bohn (2001), Smetters and Walliser (2004), Nishiyama (2002) and Smetters (2004), 
and Fehr and Habermann (2005).

This model, like our previous ones, builds on Auerbach-Kotlikoff's (1987) overlapping generation (OLG) model. Auerbach and Kotlikoff also simulated demographic transitions, but their model assumed that all agents gave birth at a fixed age, died and bequeathed at a fixed age, and received inheritances at a fixed age. Kotlikoff, Smetters, and Walliser (2001) advanced the Auerbach-Kotlikoff model by incorporating age-specific fertility and inheritance, lifespan extension, intragenerational earnings heterogeneity, and additional fiscal institutions. Fehr, Jokisch, and Kotlikoff (2004a,b, 2005) included lifespan uncertainty as well as bequests arising from incomplete annuitization. They also introduced multiple regions with international capital mobility and immigration.

As in Kotlikoff, Smetters, and Walliser (2001), our model features monozygotic reproduction with agents in their child-bearing years giving birth each year to fractions of children. This means of finessing marriage and family formation permits us to incorporate changes through time in agespecific fertility rates and to closely line up our model's age-specific population shares to those forecast for the four regions.

We assume that agents care about their children's utility when they are young and, as a consequence, make consumption expenditures on behalf of their children (pay for their consumption), but only when the children are young. We also assume that agents die with realistic mortality probabilities starting at age 68. Agents fully appreciate the uncertainty of their longevities and maximize, at any point in time, their expected remaining lifetime utilities. The inclusion of lifespan uncertainty permits a realistic modelling of bequests and inheritances.

We generate bequests by assuming that agents fail to annuitize their assets in old age. Hence, when they die, they leave undesired bequests to their children. Since agents die at different ages and have children of different ages, their heirs also inherit at different ages. Agents who were born when their parents were young receive inheritances later in their life than do their younger siblings. Finally, uninsurable lifespan uncertainty leads agents to gradually reduce their consumption in old age.

A final, but very important, feature of our framework is its intra-cohort disaggregation. As 
in Kotlikoff, Smetters and Walliser (2001), we consider three income classes within each generation each with its own earnings ability. Immigrants are also split into these income classes permitting us to simulate the arrival of immigrants with different stocks of human and physical capital. The following sections present the general structure of our model. A more detailed description of the three-country model is provided in Fehr, et al. (2003).

\section{Demographics}

Our model is populated by households who live at most to age 90 . Consequently, there are 91 generations with surviving members at any point in time. The individual life cycle of a representative agent is described in Figure 1. Between ages 0 and 20 our agents are children who earn no money and are supported by their parents. At age 21 our agents leave their parents and go to work. Between ages 23 and 45 our agents give birth to fractions of children at the beginning of each year, i.e. the first (fraction of) children are born when the agents are 23 and the last are born when they are age 45. An agent's first-born children (fractions of children) leave home when the parents are age 43, while the last-born leave when the agents are age 66. Our agents die between ages 68 and 90 . The probability of death is 1 at age 91 . Children always outlive their parents, meaning that parents always outlive grandparents. To see this note that if a parent reaches age 90 , his or her oldest children will be 67 . These are children who were born when the parent was age 23 .

In each year new immigrants in each skill and age group arrive with the same number and age distribution of children and the same level of assets as natives of the identical skill and age. Once they arrive, they act just like native Americans in terms of their labor supply and consumption choices.

To specify the current and future demographic structure, we start with year-2000 ${ }^{1}$ agespecific population $[\bar{N}(a, 2000)]$ and age-specific net-immigration $[\overline{N M}(a, 2000)]$ counts.

In constructing existing as well as future age-population counts, we have to link each initial cohort between the ages of 1 and 68 to those of their parents who are still alive. The reason is

\footnotetext{
${ }^{1}$ Although the economic model starts in year 2004, we chose year 2000 as the initial year for the population projections due to data availability.
} 
that children receive bequests from their parents, and the levels and timing of these inheritances depend on the ages of their parents. This linkage is achieved by applying past fertility rates to each cohort under age 69 in year 2000. If, for example, 15 percent of the parents of newborns in 1980 were 25 years old, then 15 percent of the 20-year-old's in year 2000 are assigned to parents age 45 .

In addition, each cohort is split into three income classes $k$. Specifically, we assume that 35 percent of each cohort belong to the lowest income class, 10 percent to the top income class, and the remaining 55 percent to the middle income class. We denote the population vector for year $\mathrm{t}$ as $N(a, t, s, k)$ where $a=1, \ldots, s=23, \ldots, 45, k=1,2,3$. The term $s$ references the age of the parent at the time of birth of agents age $a$ in 2000 .

To determine the evolution of the population in each region over time, we applied region-, age-, and year-specific mortality and fertility rates to the cohorts alive in year 2000 as well as to their children as they reach their ages of fertility and mortality. In the baseline path the exogenous current and future mortality and fertility rates follow the medium variant of the United Nations population projection (UNPD, 2003).

According to this projection, U.S. life expectancy at birth rises by 4.5 years between 2000 and 2050. Table 1 shows our models' life expectancies at birth through 2050. After 2050, mortality as well as fertility rates are kept constant to ensure the model eventually attains a steady state. The model's life expectancies at birth are higher than the official projections. But this is to be expected given that our model's agents don't die prior to age 68. However, the model's life expectancies conditional on reaching age 60 are close to those reported by the UNPD (2005).

As indicated in Table 1, the model replicates very closely the time path of the official prediction of the U.S. total fertility rate through 2050, after which we adjust the fertility rate to ensure that fertility plus net immigration, set at 1 million net immigrants per year, just reproduce the U.S. population; i.e., achieve zero population growth.

Given the population age structure in year 2000 as well as projected future fertility, mortality, and net immigration rates, we compute the population vector $N(a, t, s, k)$ for the years $t$ between 2001 and 2050. After year 2050, fertility rates are endogenously adjusted in order to achieve zero 
population growth and a stable population age structure. Since net immigration is positive in the U.S., the population-stabilizing post-2050 fertility rates is below 2.0.

Table 1 also shows projected changes over time in total populations and population age structures. Due to high fertility and net immigration rates, the U.S. population is projected to increase from 275 million in 2000 to 442 million in 2100. As the table makes clear, the model's demographic machinery does a remarkably good job matching official projections with respect to the absolute number and age compositions of their respective populations. We now describe this machinery in more detail.

The total number of children of an agent age $a$ in income class $k$ in year $t$ is recorded by the following function

$$
K I D(a, t, k)=\sum_{j=u}^{m} \frac{N(j, t, a-j, k)}{\sum_{s=23}^{45} N(a, t, s, k)} \quad 23 \leq a \leq 65, k=1,2,3
$$

where $u=\max (0 ; a-45)$ and $m=\min (20, a-23)$. Recall that agents younger than 23 have no children and those over 65 have only adult children, i.e. $K I D(a, t, k)=0$ for $0 \leq a \leq 22$ and $66 \leq a \leq 90$. Agents between these ages have children. Take, for example, a 30 year-old agent. Such an agent has children who were born in the years $(a-j)$ since she/he was 23 . In year $t$, these children are between age $0 \leq j \leq 7$. The KID-function (1) sums the total number of kids of the respective parent-income class generation and divides it by the total number of parents of age $a$ in year $t$ who belong to income class $k$. This function takes into account that the family's age structure will change over time due to changing fertility. This approach permits the distribution of births by the ages of parents to change over time - an important improvement relative to the birthing process stipulated in Kotlikoff, Smetters and Walliser (2001).

\section{The Household Sector}

As previously mentioned, we do not distinguish between natives and immigrants once the immigrants have joined the native earnings- and age-specific cohorts. The model's preference structure is represented by a time-separable, nested, CES utility function. Remaining lifetime utility $U(j, t, s, k)$ of a generation of age $j$ at time $t$ whose parents were age $s$ at time of birth and 
who belongs to income class $k$ takes the form

$$
U(j, t, s, k)=V(j, t, s, k)+H(j, t, s, k),
$$

where $V(j, t, s, k)$ records the agent's utility from her/his own goods and leisure consumption and $H(j, t, s, k)$ denotes the agent's utility from the consumption of her/his children. The two sub-utility functions are defined as follows:

$$
\begin{aligned}
& V(j, t, s, k)=\frac{1}{1-\frac{1}{\gamma}} \sum_{a=j}^{90}\left(\frac{1}{1+\theta}\right)^{a-j} P(a, i)\left[c(a, i, s, k)^{1-\frac{1}{\rho}}+\alpha \ell(a, i, s, k)^{1-\frac{1}{\rho}}\right]^{\frac{1-\frac{1}{\gamma}}{1-\frac{1}{\rho}}} \\
& H(j, t, s, k)=\frac{1}{1-\frac{1}{\gamma}} \sum_{a=j}^{90}\left(\frac{1}{1+\theta}\right)^{a-j} P(a, i) K I D(a, i, k) c_{K}(a, i, s, k)^{1-\frac{1}{\gamma}}
\end{aligned}
$$

where $c(a, i, s, k)$ and $\ell(a, i, s, k)$ denote consumption and leisure, respectively, and $i$ is defined as $i=t+a-j$. The children's consumption of income class $k$ parents who are age $a$ in period $i$ and whose parents were age $s$ at the time of their birth is defined as $c_{K}(a, i, s, k)$. Note that the number of children is independent of the grandparent's age at the time of the birth of the parents.

Since lifespan is uncertain, the utility of consumption in future periods is weighted by the survival probability of reaching age $a$ in year $i$

$$
P(a, i)=\prod_{u=j}^{a}[1-d(u, u-a+i)],
$$

which is determined by multiplying the conditional survival probabilities from year $t$ (when the agent's age is $j$ ) up to year $i$. Note that $d(j, t)$ is the mortality probability of an agent age $j$ in year $t$. The parameters $\theta, \rho, \alpha$ and $\gamma$ represent the "pure" rate of time preference, the intratemporal elasticity of substitution between consumption and leisure at each age $a$, the leisure preference parameter, and the intertemporal elasticity of substitution between consumption and leisure in different years, respectively.

In maximizing utility, agents choose their demand for leisure subject to the constraint that leisure in each period not exceed 1, which is the time endowment. The determination of the shadow values of these leisure constraints, when these constraints are binding, is included as part of the maximization. To ensure that agents retire by a designated maximum retirement age, we set the net wage at that age and thereafter to zero. 
Given the asset endowment a $(j, t, s, k)$ of the agent in year $t$, maximization of $(2)$ is subject to a lifetime budget constraint defined by the sequence:

$$
\begin{array}{r}
\mathrm{a}(j+1, t+1, s, k)=[\mathrm{a}(j, t, s, k)+I(j, t, s, k)](1+r(t))+w(t) E(a, k)[h(a, t)-\ell(a, t, s, k)] \\
-T(j, t, s, k)-c(j, t, s, k)-K I D(j, t, k) c_{K}(j, t, s, k),
\end{array}
$$

where $r(t)$ is the pre-tax return on savings and $I(j, t, s, k)$ denotes the inheritance the agent receives in year $t$. When the parents die between age 68 and 90 , their remaining assets are split between their children. Consequently, inheritances of agents who are age $j$ in year $t$ and whose parents were age $s$ at their birth are defined by:

$$
I(j, t, s, k)=\frac{d(j+s) \bar{A}(j+s, t, k)}{\sum_{u=23}^{45} N(j+s-u, t, u, k)} .
$$

The numerator defines the aggregate assets of income class $k$ parents who die in year $t$ at age $j+s$. The denominator defines these parents' total number of children who are between ages $j+s-45$ and $j+s-23$ in year $t$. The receipt of inheritances requires us to distinguish members of each cohort according to the ages of their parents at birth. The parents' ages at death determine when the children receive their inheritances. While the oldest children (born when their parents are age 23) receive their inheritances between ages 45 and 67, the youngest children (born when their parents are age 45) receive their inheritances earlier in life, between ages 23 and 45 .

As in Altig, et. al. (2001) and Kotlikoff, Smetters and Walliser (2001), we assume that technical progress causes the time endowment $h(\cdot)$ of each successive generation to grow at the rate $\lambda$, i.e.

$$
h(a, i)=(1+\lambda) h(a, i-1) .
$$

The proposition here is not that time, per se, expands for successive generations, but rather that each successive generation is more effective in using time to either preform work or enjoy leisure. Treating technical change in this manner is essential to ensure that the economy achieves a long-run steady state. The assumption of labor-augmenting technical change would not, for example, be compatible with a long-run steady state given the nature of the model's preferences. And having the economy achieve a long-run steady state provides, in effect, the terminal conditions needed by our algorithm to solve for the model's equilibrium transition path. 
Gross labor income of the agent in year $t$ is derived as the product of her/his labor supply and her/his wage rate. The latter is the product of the gross wage rate $w(t)$ in period $t$ and the age- and class-specific earnings ability.

$$
\begin{aligned}
E(a, k)=\xi(k) e^{4.47+0.033(a-20)-0.00067(a-20)^{2}}(1+\lambda)^{a-21} & \text { with } \\
& \xi(1)=0.2, \xi(2)=1.0, \xi(3)=5.0
\end{aligned}
$$

The middle-income class profile is taken from Auerbach and Kotlikoff (1987). The shift parameters $\xi(k)$ are then applied to derive income class-specific profiles. Moreover, since technological change is an important determinant of secular growth over the life cycle, we multiply the age-specific longitudinal earnings ability profile by the term involving $\lambda$. Hence, the longitudinal age-wage profile is steeper the greater is the rate of technological change.

The net taxes $T(j, t, s, k)$ of an agent in year $t$ consist of consumption, capital income, and progressive wage taxes as well as social security contributions net of pension and disability benefits received. Due to our assumed ceiling on payroll tax contributions, pension, disability insurance, and health-care average and marginal payroll tax rates differ across agents. Each agent's pension benefits depend on her/his pre-retirement earnings history, while health care and disability transfers are provided on a per capita basis to all eligible age groups.

Given individual consumption, leisure, and asset levels of all agents, we can compute aggregate variables. For example, the aggregate value of assets $A(t+1)$ in period $t$ is computed from

$$
A(t+1)=\sum_{k=1}^{3} \sum_{a=21}^{90} \underbrace{\sum_{s=23}^{45} \mathrm{a}(a+1, t+1, s, k) N(a, t, s, k)}_{\bar{A}(a+1, t+1, k)}
$$

Since households die at the beginning of each period, we have to aggregate across all agents who lived in the previous period in order to compute $\bar{A}(a+1, t+1, k)$, which we need for the calculation of bequests, see ( 7$)$. If we aggregate across agents who live in period $t+1$, i.e.,

$$
\mathcal{A}(t+1)=\sum_{k=1}^{3} \sum_{a=21}^{90} \sum_{s=23}^{45} \mathrm{a}(a, t+1, s, k) N(a, t+1, s, k)
$$

assets of the arriving immigrants of period $t+1$ are included. 
Finally, aggregate labor supply of agents in year $t, L(t)$, is computed from the individual labor supplies, i.e.

$$
L(t)=\sum_{k=1}^{3} \sum_{a=21}^{90} \sum_{s=23}^{45} E(a, k)[h(a, t)-\ell(a, t, s, k)] N(a, t, s, k) .
$$

\section{The Production Sector}

The economy is populated by a large number of identical firms, the total number of which is normalized to unity. Aggregate output (net of depreciation) is produced using Cobb-Douglas production technology, i.e.

$$
F(K(t), L(t))=\phi K(t)^{\varepsilon} L(t)^{1-\varepsilon}
$$

where $K(t)$ is aggregate capital in period $t, \varepsilon$ is capital's share in production, and $\phi$ is a technology parameter. Since we posit convex capital adjustment cost, the firms' marketable output in year $t, Y(t)$, is given by the difference between gross output and adjustment costs, i.e.

$$
Y(t)=F(K(t), L(t))-0.5 \psi \Delta K(t)^{2} / K(t)
$$

where $\Delta K(t)$ measures investment in year $t$. The term $\psi$ is the adjustment cost coefficient. Larger values of $\psi$ imply higher marginal costs of new capital goods for a given rate of investment. The installation technology is linear homogeneous and shows increasing marginal cost of investment (or, symmetrically, disinvestment): faster adjustment requires a greater than proportional rise in adjustment costs.

Corporate taxes, $T^{k}(t)$, are given by

$$
T^{k}(t)=\tau^{k}(t)[Y(t)-w(t) L(t)-\epsilon(t) \Delta K(t)]
$$

where $\tau^{k}(t)$ and $\epsilon(t)$ define the corporate tax rate and the immediate write-off share of investment expenditures, respectively. Since adjustment costs are fully, and investment expenditures are partly, deductible from the tax base, arbitrage between new and existing capital implies that the latter has a price per unit of

$$
q(t+1)=1-\epsilon(t) \tau^{k}(t)+\left[1-\tau^{k}(t)\right] \psi \Delta K(t) / K(t)
$$


Similarly, the arbitrage condition arising from profit maximization requires identical returns to financial and real investments:

$$
r(t) q(t)=\left[1-\tau^{k}(t)\right]\left\{F_{K(t)}+0.5 \psi(\Delta K(t) / K(t))^{2}\right\}+q(t+1)-q(t) .
$$

The left side gives the return on a financial investment of amount $q(t)$, while the return on one unit of real capital investment is the net return to capital (which includes the marginal product of capital $F_{K(t)}$ plus the reduction in marginal adjustment costs) and capital gains.

\section{The Government Sector}

The consolidated government issues new debt $\Delta B(t)$ and collects corporate taxes and nettaxes from households in order to finance general government expenditures $G(t)$ as well as interest payments on its debt:

$$
\Delta B(t)+T^{k}(t)+\sum_{k=1}^{3} \sum_{a=21}^{90} \sum_{s=23}^{45} T(a, t, s, k) N(a, t, s, k)=G(t)+r(t) B(t) .
$$

With respect to public debt, we assume that the government maintains an exogenously fixed ratio of debt to output. The progressivity of the wage tax system is modeled as in Auerbach and Kotlikoff (1987). Specifically, marginal wage tax rates rise linearly with the tax base.

$P Y(t)$ defines the aggregate payroll tax base, which differs from total labor earnings due to the ceiling on taxable wages. This ceiling is fixed at 250 percent of average annual earnings. Aggregate average social security payroll tax rates $\hat{\tau}^{p}, \hat{\tau}^{h}$ and $\hat{\tau}^{d}$ are computed each period from the budget constraint relevant for the program in question, i.e.

$$
\hat{\tau}^{p}(t) P Y(t)=P B(t) \quad \hat{\tau}^{h}(t) P Y(t)=H B(t) \quad \text { and } \quad \hat{\tau}^{d}(t) P Y(t)=D B(t)
$$

where $P B(t), H B(t)$ and $D B(t)$ are total outlays of the pension, health care, and disability systems, respectively.

Due to contribution ceilings, individual pension, disability and health insurance payroll tax rates can differ from the payroll tax rate. Above the contribution ceiling, marginal social security contributions are zero and average social security contributions fall with the agent's income. To accommodate this non-convexity of the budget constraint, we assume that the highest earnings 
class pays the FICA OASDI payroll tax up to the ceiling, but faces no payroll taxes at the margin. The other earnings classes are assumed to face the full statutory OASDI tax rate on all earnings. However, since there is no ceiling on the HI FICA tax, all earnings groups are assumed to face the HI tax at the margin.

If a $k$-income class agent,whose parents were $s$ years old at his birth, retires in year $z$ at the exogenously set retirement age $\bar{a}(z)$, her/his pension benefits $\operatorname{Pen}(a, i, s, k)$ in years $i \geq z$ when he is age $a \geq \bar{a}(z)$ depend linearly on her/his average earnings during his working time $\bar{W}(z, s, k)$ :

$$
\operatorname{Pen}(a, i, s, k)=\omega_{0}+\omega_{1} \times \bar{W}(z, s, k) .
$$

The parameters $\omega_{0}, \omega_{1}$ were chosen in order to approximate replacement rates relative to individual lifetime earnings as reported in Whitehouse (2002).

General government expenditures $G(t)$ consist of government purchases of goods and services, including educational expenditures and health outlays. Over the transition, general government purchases of goods and services are held fixed as a percent of national income. Age-specific education and disability outlays are held fixed per capita over the transition with an adjustment for technological change. Age-specific health outlays are also held fixed per capita, but are assumed to grow at twice the rate of technological change during the first 25 years of the transition. Afterwards, the age-specific levels of these outlays grow at the same rate as technological change. Note that while the outlays of the health care systems are treated as government expenditures, disability benefits are modeled as direct transfers to the households. The government's budget (18) is balanced each year by adjusting the intercept in our linear equation determining the average wage tax rate.

\section{Solving the Model}

To simulate the model we need, of course, to specify preference, technology, and policy parameters. Table 2 reports these values, which, in the case of preference and technology parameters, are mostly taken from Kotlikoff, Smetters and Walliser (2001).

The multi-factor technology coefficient in the U.S. Cobb-Douglas function was set to generate a U.S. marginal product of labor of 1.0 in the initial year 2004. The time-preference rate was set to 
match the model's 2004 ratio of private consumption to national income to the U.S. ratio reported in European Commission (2005).

The model's debt level was chosen to accord with real government interest payments reported in European Commission (2005) for the year 2004. The maximum age of retirement is taken from Bloendal and Scarpetta (1999) for the U.S. We set the excise tax rate, personal capital income tax rate, corporate income tax rate, and expensing rate in line with the structure of indirect and direct tax revenues reported in European Commission (2005).

Our wage tax systems are assumed to be progressive, with the parameters of these tax systems in each region set so as to generate what seem to be realistic average and marginal tax rates, which are reported below.

We set the marginal effective corporate income tax rate equal to 30 percent. To ensure the correct ratio of corporate income tax revenue to national income, we also provide an inframarginal lump-sum transfer of corporate income tax revenues to households each year. This transfer is provided in proportion to each household's asset holdings.

In simulating the FairTax, we set the rebate, which is provided to all agents regardless of income to yield a 23 percent effective FairTax rate in our FairTax closed as well as open economy simulations.

We assume uniform Medicare expenditures by age for those 65 and older and uniform disability benefit payments for those 20 to 65 . Total social insurance outlays for pensions, disability, and health, measured as a share of national income, are set to accord with the values of these totals reported in European Commission (2005). We calculated a U.S. age-wealth profile using the 1998 Survey of Consumer Finances. The model's initial asset level was set to generate a 2004 capital-output ratio of 3.0 .

Initial (year 2004) asset holdings, the ratio of government debt to national income, and the inter- and intragenerational distribution of assets constitute the initial conditions needed to solve for the perfect foresight general equilibrium transition path of the economy. The algorithm we use to solve the model employs Gauss-Seidel iteration and the assumption that the economy has 
achieved a steady state by the year 2300. This assumption provides, in effect, terminal conditions to help solve for the economy's perfect foresight transition path.

Specifically, our algorithm starts with initial guesses of the aggregate demands for capital stocks and labor supplies for the post-2004 years of the transition. Next we compute from the profit maximizing factor demand conditions the paths of wage rates and interest rates consistent with these guessed factor demands. Step three uses these pre-tax factor prices to determine aggregate household supplies of assets and labor in each transition year.

The first-order conditions and lifetime budget constraints determining household labor and asset supplies are complex and certainly do not omit of closed form solutions. Part of this complexity arises because of the progressive nature of our assumed wage tax structures, which means that marginal tax rates are themselves endogenous and need to be determined jointly with life-cycle consumption, saving, and labor supply decisions. This is also done using Gauss-Seidel iteration. We refer to this as "inter-loop" convergence. As indicated momentarily, we also use Gauss-Seidel iteration to determine the time path of the economy's macroeconomic variables. We refer to this iteration on macro variables as "outer-loop" convergence.

The next step in our overall solution algorithm uses the annual revenues and Social Security benefit payments implied by these household decisions to update annual tax rates/tax parameters. We also update the model's region-specific time paths of government debt. These updates are based on equations (18) and (19).

Aggregating individual labor supplies in each year provides a new time path of aggregate labor supply. The corresponding new time path of the household sector's supply of capital is determined by subtracting government debt from total household sector asset supply in each future year. Next, we form a weighted average of the initial guessed time paths of capital and labor and the aggregate supplies of these factors derived from household behavior. These weighted averages for each year are then used as the new guess for the aggregate demand for capital and labor. The algorithm continues in this manner until it converges to many decimal places.

As indicated, we give our economy 300 years to reach to a steady state. In fact, our model reaches a steady state to many decimal places decades prior to year 300. It also converges very 
tightly around the equilibrium transition path.

We can run our model as either a closed economy or an open economy. In the open economy simulation presented below, we peg the economy's post-corporate tax rate of return at the year 2004 value in our closed economy simulation.

To accommodate the FairTax's insulation of the real purchasing power of Social Security benefits, we raise the size of these benefits by 30 percent, which is the FairTax retail sales tax rate. In implementing the FairTax we also impose an 18 percent permanent cut in government purchases of goods and services starting in our 2004 base year. This may seem like a substantial reduction in discretionary federal spending, but one needs to bear in mind that such spending has increased by 22.2 percent since 2000 measured as a share of national income.

\section{The U.S. Baseline Transition Path}

Table 3 reports key macroeconomic variables in 2004 in the four regions. There is very close accordance between actual and computed values of private consumption and government purchases measured as a share of national income. The reported ratio of educational expenditure to national income is also targeted well by our model ${ }^{2}$. The model also we closely matches the share of national income received in the form of social contributions as reported in European Commission (2005). On the other hand, our model's pension OASI contribution rate is significantly lower than the official rate. This appears to reflect the limitations of having only three earnings groups within each cohort - a limitation arising from computational considerations. Finally, the model does a reasonably good job generating the right ratios of direct and indirect taxes to national income.

Next we turn to the baseline closed-economy simulation results, reported in the top panel of table 4. In examining this table, note that the values of national income, the capital stock, the supply of labor, the Social Security payroll tax rate, and the pre-tax wage rate are all expressed relative to their respective values in 2004.

The first column of table 4 shows that neither America's aging nor its associated increase in payroll taxes prevents the economy from growing in absolute terms. Indeed, the model's output

\footnotetext{
${ }^{2}$ See OECD (2003a, 178; 2003b, 71, 77).
} 
in 2100 is 3.86 times its 2004 value. This reflects growth over time in the supplies of both labor and capital, which expand by factors of 4.06 and 3.35, respectively, over the course of the century.

The growth of labor supply, shown in column 3, primarily reflects our assumption that each successive cohort has a higher effective time endowment, which admits greater effective labor supply by each successive cohort. Other things equal, this rising supply of effective labor means rising labor income and, therefore, more wherewithal for workers to save for retirement. The

additional saving is, of course, invested, explaining the model's predicted growth in the stock of capital (see column 2).

Due to the aging of the populations, the models' social security cost rate (the model's payroll tax rate) more than doubles over the century. Average wage tax rates, on the other hand, change very little over time.

While the supplies of both labor and capital rise over time, growth in the supply of labor outpaces growth in the supply of capital thanks, in large part, to the very substantial rise in overall taxation of labor income. Consequently, capital per unit of human capital falls over time, leading to a 5.0 percent decline over the course of the century in the pre-tax wage per unit of human capital. Thus, in the base-case, no-tax reform simulation we see a long-run capital shortage, albeit a moderate one.

However, in combination with the model's predicted rise in the payroll tax, the decline in the pre-tax wage spells an 18.0 percent decline in long-run after-tax take-home-pay. It also spells a major reduction in welfare, which, as we'll now show can be avoided via a switch to the FairTax.

\section{The FairTax Transition Path}

Table 4's second panel reports the transition path arising from eliminating the personal wage income tax, the personal capital income tax, the corporate income tax, and the payroll tax and replacing them with a consumption tax plus a rebate.

The effective FairTax tax rate required to finance this reform is given in the last column of the table. In 2004 the model's FairTax rate is the 23 percent rate specified in HR25, the House bill that would implement the FairTax. Over time, the FairTax tax rate rises to 29. This rise reflects, 
of course, the need to pay the pension and health care costs of an increasingly aged society.

As indicated above, switching to consumption taxation provides much better saving incentives. It also redistributes resources from older spenders to younger savers. We see this in the growth of the capital stock through time. As the second column in the lower panel shows, the capital stock ends up dramatically higher in the long run under the FairTax then it does under the current tax system. Indeed, the capital stock in 2100 is 83.3 percent higher. While the expansion of the capital stock proceeds relatively slowly,its noticeable even by 2010. In that year, the capital stock is 13.0 percent higher under the FairTax than would otherwise have been the case. By 2030, the capital stock is 41.4 percent higher than in the status quo transition.

The significant rise in capital formation permits two things - an expansion of U.S. output and an increase in leisure. As column 1 of table 4 shows, output in 2100 is $10.6((4.27-3.86) / 3.86)$ percent higher thanks to the FairTax even though the supply of labor is $7.4((3.80-4.06) / 4.06)$ percent smaller.

The increased capital formation also leads to a rise in the real wage per unit of human capital. Rather than declining by 5.0 percent by the end of the century, the real wage now rises by 13.0 percent. This is 18.0 percent difference in real worker remuneration. Again, the pace of change is slow, but by 2030 real wages under the FairTax are 9.3 percent higher than they would otherwise have been.

In transforming the economy's prospects from one of a capital shortage to one of capital deepening, the FairTax also reduces real interest rates, with the 2100 real interest rate ending up 150 basis points lower than in the base case.

\section{Welfare Effects of Switching to the FairTax}

Table 5 shows the remarkably large and highly progressive welfare gains arising for most members of current and future cohorts from the switch to the FairTax. These welfare changes are measured as the uniform percentage change in an agent's current and future consumption and leisure in the base-case economy required to achieve the same level of remaining lifetime utility as the agent enjoys under the FairTax. 
Look first at the results for those born in 1920, i.e., those who are 84 at the time of the reform. The low-income members of this cohort experience a sizeable 14.4 percent welfare gain. Their middle-income contemporaries experience a moderate 2.1 percent welfare gain, while their richer contemporaries experience a small .5 percent welfare loss.

This picture of substantial welfare gains for low-income cohort members and modest gains or small losses for middle- and high-income cohort members holds for all cohorts born before 1970. For cohorts born after 1970 we see major welfare gains not just for low-income cohort members, but for middle- and high-income members as well. But the gains to the low-income members are much higher than those of their contemporaries. Take the cohort born in 2030. Low-income members experience a 26.7 percent welfare gain, while their middle-income contemporaries experience a 10.9 percent gain, and their high-income contemporaries experience a 4.7 percent gain.

What explains the pattern of these welfare changes? The answer is in part the wealth tax component of the FairTax, in part the FairTax's preservation of the purchasing power of Social Security benefits, in part the introduction of the highly progressive rebate, in part the elimination of the highly regressive payroll tax, in part the major rise in real wages, in part the cutback on federal discretionary spending, and, in part, the major reduction in economic distortion arising from a tax structure that eliminates the taxation of saving and, for many households, significantly reduces the total effective tax on labor supply.

Consider, for example, members of income class 1 who were born in 1920 and enjoy a 14.4 percent welfare gain. This gain can be traced to the fact that these households depend almost entirely on Social Security to finance their consumption. The FairTax not only preserves the purchasing power of their Social Security benefits. It also provides them with the FairTax rebate. The rebate, recall, is based on demographics, not on income; i.e., all households receive the rebate regardless of income. Hence, these households are overcompensated by the FairTax and end up better off as a result.

Next, consider members of income class 1 born in 2030. What is the precise explanation for their 26.7 percent welfare gain? The answer begins with the fact that, thanks to the FairTax, they receive a pre-tax wage at the start of their work careers that is 14.9 percent than it would 
otherwise have been. By the end of their work careers, their pre-tax wage is 18.9 percent higher than it would otherwise have been. In addition, they receive the FairTax rebate. Hence, these households pay relatively little in taxes on net and face an average net tax on their labor earnings of only 5 percent. In contrast, their average net tax under the status quo regime ranges from 19.5 percent to 23.6 percent thanks simply to Social Security (FICA) payroll taxation. Finally, these households experience substantial efficiency gains thanks to the FairTax's complete elimination of the taxation of saving.

\section{Open Economy Results}

Tables 6 and 7 present the economic and welfare results from switching to the FairTax under the assumption that the U.S. is perfectly open to international capital inflows. Table 6's index values are normalized at the year-2004 close economy levels, i.e., the values shown are relative to the values prevailing in 2004 in the closed economy. As in our closed economy simulation, there are major economic and welfare gains from adopting the FairTax. However, these gains are smaller than in the closed economy results.

The variable of chief interest - the pre-tax wage - rises in this simulation by 11.1 percent over the course of the century. This is less than the 18.9 percent rise in the closed economy simulation, but still sizable.

As in the closed economy case, the rise in the pre-tax wage can be traced to higher levels of capital per worker. In the closed economy simulation, the increased saving of U.S. households, in response to the FairTax's redistributive and incentive effects, led, over time, to more capital formation. In the open economy case, the source of increased capital formation is the elimination, under the FairTax reform, of the model's assumed 30 percent effective corporate income tax. The reason is that in an open economy, capital flows in from abroad when it can get a higher return due to a reduction in corporate taxes. It continues to do so until the pre-tax return is sufficiently lowered as to make the after-tax return the same as that available abroad. In the present simulation, the rise in U.S. capital formation is substantial, with the capital stock in 2100 40.4 percent higher than in the base case simulation.

Although the capital stock increases smartly over time, the economy's supply of labor fails 
to keep pace leaving the overall output of the economy in 2100 at roughly the same level that prevails without the FairTax. In the closed economy switch to the FairTax, the system's effective tax rate rose from 23 percent to 29 percent. The same rise occurs in the open economy simulation.

Table 7 presents open-economy welfare effects from tax reform. As in the closed economy simulation, the welfare gains accruing to old, middle aged, young, and future poor households are remarkably large on the one right and much larger than those experienced by their middle class and rich contemporaries. Indeed, the only major difference between tables 7 and 5 is the slightly smaller welfare gain experienced by those born after 1990 in income class 1.

\section{Conclusion}

The aging of the U.S. coupled with its high and growing pension and old age health care benefits augers much higher payroll taxes, with potentially damaging effects on the macroeconomy. This prognosis is supported by our base case simulation, which generates more than a doubling of the payroll tax rate as well as a modest, but significant long-run capital shortage. This crowding out of capital gradually reduces real wages per unit of human capital by 5 percent. In combination with the long-run 12 percentage point rise in the payroll tax, the model's predicted long-run reduction in worker take-home-pay is 17 percent.

The FairTax offers an alternative to this dismal economic future. The FairTax proposes to replace the federal payroll tax,personal income tax, corporate income tax, and estate tax (not modeled here) with a federal retail sales tax plus a rebate. In switching from taxing income to taxing consumption and adding a highly progressive rebate, the FairTax introduces many progressive elements into our fiscal system, removes one very regressive element (the payroll tax), and provides much better incentives to work and save.

According to our model, switching to the FairTax would raise long-run capital intensity, raising long-run real wages by 19 percent compared to the base case alternative. The reform also generates major welfare gains for the poorest members of society, including those now retired and those yet to be born. The remarkable finding of this study is how small are the transition costs associated with this reform. Yes, some initial high- and middle-income households are made worse off, but their welfare losses are minor compared with the gains available to future generations, 
particularly the poorest members of future generations.

The economic and welfare gains from switching to the FairTax are somewhat smaller if one models the U.S. economy as fully open to international capital flows. But these gains are nonetheless large and very significant.

While our model is highly stylized, it suggests that the FairTax offers a real opportunity to improve the U.S. economy's performance and the wellbeing of the vast majority of citizens. The winners from this reform, primarily those who are least well off, experience very major gains, and the losers experience only minor losses. 


\section{References}

Altig, D., A.J. Auerbach, L.J. Kotlikoff, K.A. Smetters and J. Walliser, 2001, "Simulating Fundamental Tax Reform in the United States," American Economic Review 91, 574-595.

Auerbach, A. J., 1996, "Tax Reform, Capital Accumulation, Efficiency, and Growth," in H. J. Aaron and W. G. Gale, eds., Effects of Fundamental Tax Reform, Washington, D.C.: The Brookings Institution.

Auerbach, A. J. and L. J. Kotlikoff, 1987, Dynamic Fiscal Policy, Cambridge, England: Cambridge University Press.

Auerbach, A. J. and L. J. Kotlikoff , 1983, "An Examination of Empirical Tests of Social Security and Savings," in E. Helpman et. al., eds., Social Policy Evaluation: An Economic Perspective, San Diego, Ca.: Academic Press.

Auerbach, A. J., Hagemann, R., Kotlikoff, L. J. and G. Nicoletti, 1989, "The Economics of Aging Populations: The Case of Four OECD Countries," OECD Economic Studies 12, 97-130.

Bohn, H., 2001, "Social Security and Demographic Uncertainty: The Risk Sharing Properties of Alternative Policies," John Campbell and Martin Feldstein, eds., Risk Aspects of Investment Based Social Security Reform, Chicago: University of Chicago Press, 203241.

Blöndal, S. and S. Scarpetta, 1998, "The Retirement Decision in OECD Countries," Economics Department Working Paper No. 202, OECD, Paris.

Browning, M., Hansen, L. P. and J. J. Heckman, 1998, "Micro Data and General Equilibrium Models," manuscript, University of Chicago, Chicago.

Blundell, R., Meghir, C. and P. Neves, 1993, "Labour Supply and Intertemporal Substitution," Journal of Econometrics 59, 137-60.

Cooley, T. F. and J. Soares, 1999a, "A Positive Theory of Social Security Based on Reputation," Journal of Political Economy 107, 135-60. 
Cooley, T. F. and J. Soares, 1999b, "Privatizing Social Security," Review of Economic Dynamics $2,731-55$.

De Nardi, M., Imrohoroglu, S. and T. J. Sargent, 1999, "Projected U.S. Demographics and Social Security," Review of Economic Dynamics 2, 575-615.

Docteur, E. and H. Oxley, 2003, "Health-Care Systems: Lessons from the Reform Experience," Economics Department Working Paper No. 374, OECD, Paris.

European Commission, 2003, The Budgetary Challenges Posed by Ageing Populations, European Economy: Reports and Studies No. 4 2001, Brussels.

European Commission, 2005, Statistical Annex to European Economy, Spring 2005, http://europa.eu.int/comm/economy_finance/publications/european_economy/ statisticalannex_en.htm, July 1, 2005.

Fehr, H. and C. Habermann, 2005, "Risk Sharing and Efficiency Implications of Government Pension Arrangements," mimeo, University of Wuerzburg.

Fehr, H., G. Halder, S. Jokisch and L.J. Kotlikoff, 2003, "A Simulation Model for the Demographic Transition in the OECD - Data Requirements, Model Structure and Calibration," Wuerzburg Economic Papers No. 45, University of Wuerzburg.

Fehr, H., S. Jokisch and L.J. Kotlikoff, 2004a, "Fertility, Mortality, and the Developed World's Demographic Transition," CESifo Working Paper No. 1326, Munich.

Fehr, H., S. Jokisch and L.J. Kotlikoff, 2004b, "The Role of Immigration in Dealing with Developed World's Demographic Transition," Finanzarchiv 60, 296-324.

Fehr, H., S. Jokisch and L.J. Kotlikoff, 2005a, "The Developed World's Demographic Transition - The Roles of Capital Flows, Immigration, and Policy," in: R. Brooks and A. Razin, eds., Social Security Reform - Financial and Political Issues in International Perspective, Cambridge, 11-43. 
Fehr, H., S. Jokisch and L.J. Kotlikoff, 2005b, "Will China Eat Our Lunch or Take Us to Dinner? Simulating the Transition Paths of the U.S., EU, Japan, and China," Finanzarchiv 60, 296-324.

Feldstein, M.S., 1974, "Social Security, Induced Retirement, and Aggregate Capital Accumulation," Journal of Political Economy 82, 905-926.

Feldstein, M.S. and C. Horioka, 1980, "Domestic Saving and International Capital Flows," Economic Journal, 90, 314-29.

Fullerton, D. and J. L. Coronado, and T. Glass, 2002, "Long-Run Effects of Social Security Reform Proposals on Lifetime Progressivity," in: Martin S. Feldstein and Jeff Liebman, eds., The Distributional Effects of Social Security Reform (University of Chicago Press, Chicago) 149-196.

Fullerton, D. and D. L. Rogers, 1993, Who Bears the Lifetime Tax Burden? Washington, D.C.: The Brookings Institution.

Hansson, I. and C. Stuart, 1989, Social Security as Trade Among Living Generations, American Economic Review 79, 1182-95.

Heckman, J. J., Lochner, L., and C. Taber, 1998, Tax Policy and Human Capital Formation, American Economic Review 88, 293-97.

Huang, H., Imrohoroglu, S. and T. Sargent, 1997, Two Computational Experiments to Fund Social Security, Macroeconomic Dynamics 1, 7-44.

Hubbard, G. R. and K. L. Judd, 1987, Social Security and Individual Welfare: Precautionary Saving, Borrowing Constraints, and the Payroll Tax, American Economic Review 77, 630 46.

Huggett, M. and G. Ventura, 1999, On the Distributional Effects of Social Security Reform, Review of Economic Dynamics 2, 498-531.

Imrohoroglu, A., Imrohoroglu, S. and D. H. Joines, 1999, Social Security in an Overlapping Generations Economy with Land, Review of Economic Dynamics, 2, 638-65. 
Imrohoroglu, A., Imrohoroglu, S. and D. H. Joines, 1995, A Life Cycle Analysis of Social Security, Economic Theory 6, 83-114.

Kotlikoff, L. J., 1979, Social Security and Equilibrium Capital Intensity, Quarterly Journal of Economics, 93, 233-54.

Kotlikoff, L. J., 1996, Privatizing Social Security: How It Works and Why It Matters, in: J. M. Poterba, ed., Tax Policy and the Economy 10, 1-32.

Kotlikoff, L. J. and D. Rapson, 2005, Would the FairTax Raise or Lower Marginal and Average Taxes?, forthcoming, NBER working paper.

Kotlikoff, L. J., Smetters, K. and J. Walliser, 1998a, The Economic Impact of Privatizing Social Security, in: H. Siebert, ed., Redesigning Social Security (J.C.B. Mohr, Tübingen) 327-48.

Kotlikoff, L. J., Smetters, K. and J. Walliser, 1998b, Social Security: Privatization and Progressivity, American Economic Review 88, 137-41.

Kotlikoff, L. J., Smetters, K. and J. Walliser, 1999, Privatizing Social Security in the U.S. Comparing the Options, Review of Economic Dynamics 2, 532-74.

Kotlikoff, L. J., Smetters, K. and J. Walliser, 2002, Distributional Effects in a General Equilibrium Analysis of Social Security, in: M. S. Feldstein and J. Liebman, eds., The Distributional Effects of Social Security Reform (University of Chicago Press, Chicago) 327-61.

Kotlikoff, L.J., K.A. Smetters and J. Walliser (2001): Finding a Way out of America's Demographic Dilemma, NBER Working Paper No. 8258, Cambridge.

Kraay, A., N. Loayza, L. Servén and J. Ventura (2000): Country Portfolios, NBER Working Paper No. 7795, Cambridge.

Laitner, J., 1984, Transition Time Paths for Overlapping Generations Models, Journal of Economic Dynamics and Control 7, 111-29.

Lee, R. D. and L. Carter, 1992, Modelling and Forecasting the Time Series of U.S. Mortality, Journal of the American Statistical Association 87, 659-71. 
MaCurdy, T. E., 1981, An Empirical Model of Labor Supply in a Life-Cycle Setting, Journal of Political Economy 89,1059-85.

Mulligan, C. B., 1998, Substitution Over Time: Another Look at Life-Cycle Labor Supply, in: B. S. Bernanke and J. J. Rotemberg, eds., NBER Macroeconomics Annual 1998 (MIT Press, Cambridge, MA) 75-134.

Nashiyama, S. and K. Smetters, "Consumption Taxes and Economic Efficiency in a Stochastic OLG Economy," Journal of Political Economy, 2004.

OECD (2001): Ageing and Income: Financial Resources and Retirement in 9 OECD Countries, Paris.

OECD (2002): China in the World Economy: The Domestic Policy Challenges, Paris.

OECD (2003a): Education at a glance: OECD Indicators 2003, Paris.

OECD (2003b): Financing Education - Investments and Returns: Analysis of the world education indicators, 2002 Edition, Paris.

Raffelhüschen, B., 1989, Anreizwirkungen des Systems der sozialen Alterssicherung. Eine dynamische Simulationsanalyse (Peter Lang, Frankfurt a.M.).

Raffelhüschen, B., 1993, Funding Social Security Through Pareto Optimal Conversion Policies, in: B. Felderer, ed., Public Pension Economics, Journal of Economics/Zeitschrift für Nationalökonomie, Suppl. 7, 10531.

OECD (2003c): Revenue Statistics 1965-2002, Paris.

Siegel, J., 2005, The Future for Investors," New York: Crown Business.

Seidman, L. S., 1986, A Phase-Down of Social Security: The Transition in a Life Cycle Growth Model, National Tax Journal, 97-107.

Smetters, K. and J. Walliser, 2004, Opting Out of Social Security, Journal of Public Economics $88,1295-1306$. 
Social Security Advisory Board, 1999, The 1999 Technical Panel on Assumptions and Methods (Social Security Advisory Board, Washington, D.C.).

Tuljapurkar, S., N. Li and C. Boe (2000): A universal pattern of mortality decline in the G7 countries, Nature 405, 789-792.

United Nations Population Division (UNPD) (2003): World Population Prospects: The 2002 Revision, http://esa.un.org/unpp/, (June 11, 2003).

United Nations Population Division (UNPD) (2005): World Population Prospects: The 2004 Revision, http://esa.un.org/unpp/, (June 29, 2005).

Whitehouse, E. (2002): Pension Systems in 15 Countries Compared: The Value of Entitlements, Discussion Paper 02/04, Centre for Pensions and Superannuation, Sydney.

WHO (2004): The World Health Report 2004, Geneva.

Ziliak, J. P. and T. J. Kniesner, 1999, Estimating Life Cycle Labor Supply Effects, Journal of Political Economy 107, 326-59. 
Figure 1: The individual life-cycle

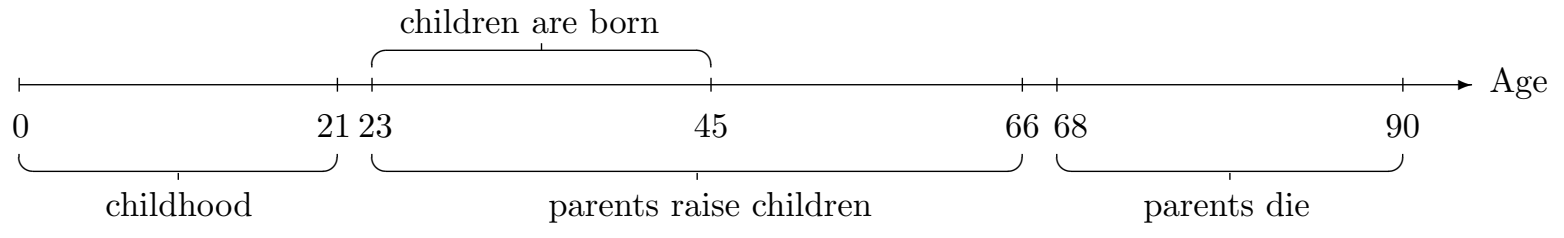


Table 1: Comparing Actual and Simulated Population Projections Population Projection U.S.

\begin{tabular}{|c|c|c|c|c|c|c|c|c|}
\hline \multicolumn{2}{|l|}{ Year } & 2000 & 2010 & 2020 & 2030 & 2040 & 2050 & 2100 \\
\hline \multicolumn{9}{|c|}{ Fertility Rate } \\
\hline \multicolumn{2}{|c|}{ Model } & 2.11 & 2.05 & 2.00 & 1.95 & 1.90 & 1.85 & 1.77 \\
\hline \multicolumn{2}{|c|}{ Official $^{a}$} & 2.11 & 2.08 & 2.03 & 1.95 & 1.89 & 1.85 & - \\
\hline \multicolumn{9}{|c|}{ Life Expectancy at Birth } \\
\hline \multicolumn{2}{|c|}{ Model } & 81.7 & 82.1 & 82.5 & 83.0 & 83.4 & 83.8 & 83.8 \\
\hline \multicolumn{2}{|c|}{ Official $^{a}$} & 77.1 & 78.3 & 79.1 & 79.9 & 81.0 & 81.6 & - \\
\hline \multicolumn{9}{|c|}{ Total Population $^{b}$} \\
\hline \multicolumn{2}{|c|}{ Model } & 276.2 & 307.3 & 340.0 & 366.4 & 385.8 & 400.3 & 442.0 \\
\hline \multicolumn{2}{|c|}{ Official $^{a}$} & 285.0 & 314.9 & 344.3 & 370.4 & 391.4 & 408.7 & - \\
\hline \multicolumn{9}{|c|}{ Age Structure $^{c}$} \\
\hline \multirow[t]{2}{*}{$<15$} & Model & 21.6 & 20.1 & 19.7 & 18.5 & 18.2 & 17.8 & 15.9 \\
\hline & Official $^{a}$ & 21.8 & 20.5 & 20.0 & 19.3 & 18.5 & 17.9 & - \\
\hline \multirow[t]{2}{*}{$15-64$} & Model & 66.2 & 67.2 & 64.0 & 61.4 & 61.7 & 62.1 & 60.7 \\
\hline & Official $^{a}$ & 65.9 & 66.6 & 64.1 & 61.5 & 61.7 & 62.1 & - \\
\hline \multirow[t]{2}{*}{$65-90$} & Model & 12.2 & 12.7 & 16.3 & 20.1 & 20.2 & 20.1 & 23.3 \\
\hline & Official $^{a}$ & 12.3 & 12.8 & 15.9 & 19.2 & 19.8 & 20.0 & - \\
\hline
\end{tabular}


Table 2: Parameter Values of the Model

Symbol Value

Utility Function

$\begin{array}{lll}\text { Time preference rate } & \theta & 0.01\end{array}$

Intertemporal elasticity of substitution $\gamma \quad 0.25$

Intratemporal elasticity of substitution $\quad \rho \quad 0.40$

$\begin{array}{lll}\text { Leisure preference parameter } & \alpha & 1.50\end{array}$

Production Function

Technology level

Capital share in production

$\phi \quad 1.01$

Technical progress

$\varepsilon \quad 0.25$

Policy Parameters

Excise tax rate (in \%)

$\lambda \quad 0.01$

Personal capital income tax rate (in \%) $\tau^{r}$

Marginal corporate tax rate (in \%) $\tau^{k}$

$\tau^{c} \quad 10.2$

Expensing rate (in \%)

Debt (in \% of national income)

$\epsilon \quad 0.0$

Age of retirement

$B / Y \quad 33.3$

63 
Table 3 The Year 2004 of the Baseline Path ${ }^{a}$

\begin{tabular}{|c|c|c|}
\hline & Model & Official $^{b}$ \\
\hline \multicolumn{3}{|l|}{ National Income } \\
\hline Private consumption & 78.8 & 79.3 \\
\hline $\begin{array}{l}\text { Government purchases of goods } \\
\text { and services }\end{array}$ & 17.4 & 17.4 \\
\hline General public expenditures & 9.6 & - \\
\hline Aggregate education outlays & 5.9 & 5.9 \\
\hline Aggregate health benefits & 1.9 & 2.5 \\
\hline \multicolumn{3}{|l|}{ Government Indicators } \\
\hline Social contributions received & 8.1 & 7.9 \\
\hline Aggregate pension benefits & 5.3 & 5.7 \\
\hline Aggregate health benefits & 1.9 & 2.5 \\
\hline Aggregate disability benefits & 0.9 & 0.9 \\
\hline Pension contribution rate ${ }^{c}$ & 7.7 & 10.6 \\
\hline Health-care contribution rate ${ }^{c}$ & 2.6 & 2.9 \\
\hline $\begin{array}{l}\text { Disability-insurance contribution } \\
\text { rate }^{c}\end{array}$ & 1.4 & 1.9 \\
\hline Interest payment on public debt ${ }^{c}$ & 3.4 & 3.0 \\
\hline Tax revenues ${ }^{c}$ & 18.9 & 20.6 \\
\hline Direct taxes & 10.9 & 12.5 \\
\hline Personal income taxes & 7.9 & 9.5 \\
\hline Wage taxes & 5.5 & - \\
\hline Capital taxes & 2.4 & - \\
\hline Corporate income taxes & 3.0 & 3.0 \\
\hline Indirect taxes & 8.0 & 8.1 \\
\hline \multicolumn{3}{|l|}{ Wage tax rates ${ }^{c}$} \\
\hline Average & 7.5 & - \\
\hline Marginal & 13.9 & - \\
\hline Capital-output ratio & 2.2 & - \\
\hline Capital-labor ratio & 3.0 & - \\
\hline Interest rate ${ }^{c}$ & 7.5 & - \\
\hline
\end{tabular}

${ }^{a}$ in percent of national income if not stated differently;

${ }^{b}$ European Commission (2005); ${ }^{c}$ in percent. 


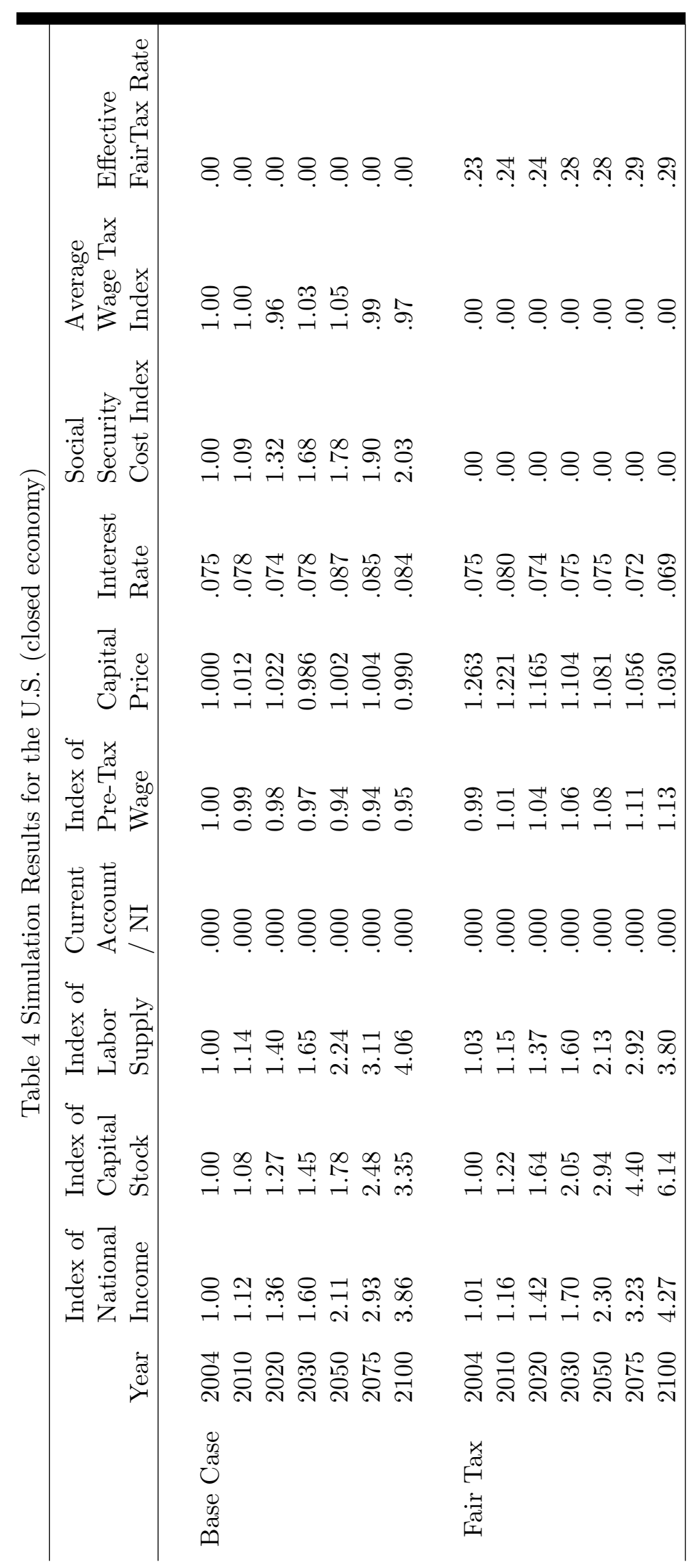


Table 5 Welfare Effects (closed economy)

\begin{tabular}{l|rrr}
\hline Birth & \multicolumn{3}{|c}{ Income Class } \\
Year & 1 & 2 & 3 \\
\hline 1920 & 14.39 & 2.14 & -0.46 \\
1930 & 13.71 & 1.47 & -0.65 \\
1940 & 13.02 & 0.96 & -1.02 \\
1950 & 8.27 & -0.40 & -1.33 \\
1960 & 8.56 & -0.10 & -1.11 \\
1970 & 11.24 & 1.66 & 0.08 \\
1980 & 12.93 & 3.14 & 1.59 \\
1990 & 16.18 & 4.88 & 2.36 \\
2000 & 20.51 & 7.22 & 3.28 \\
2010 & 23.76 & 9.12 & 4.05 \\
2020 & 25.50 & 10.21 & 4.46 \\
2030 & 26.73 & 10.92 & 4.71 \\
\hline
\end{tabular}




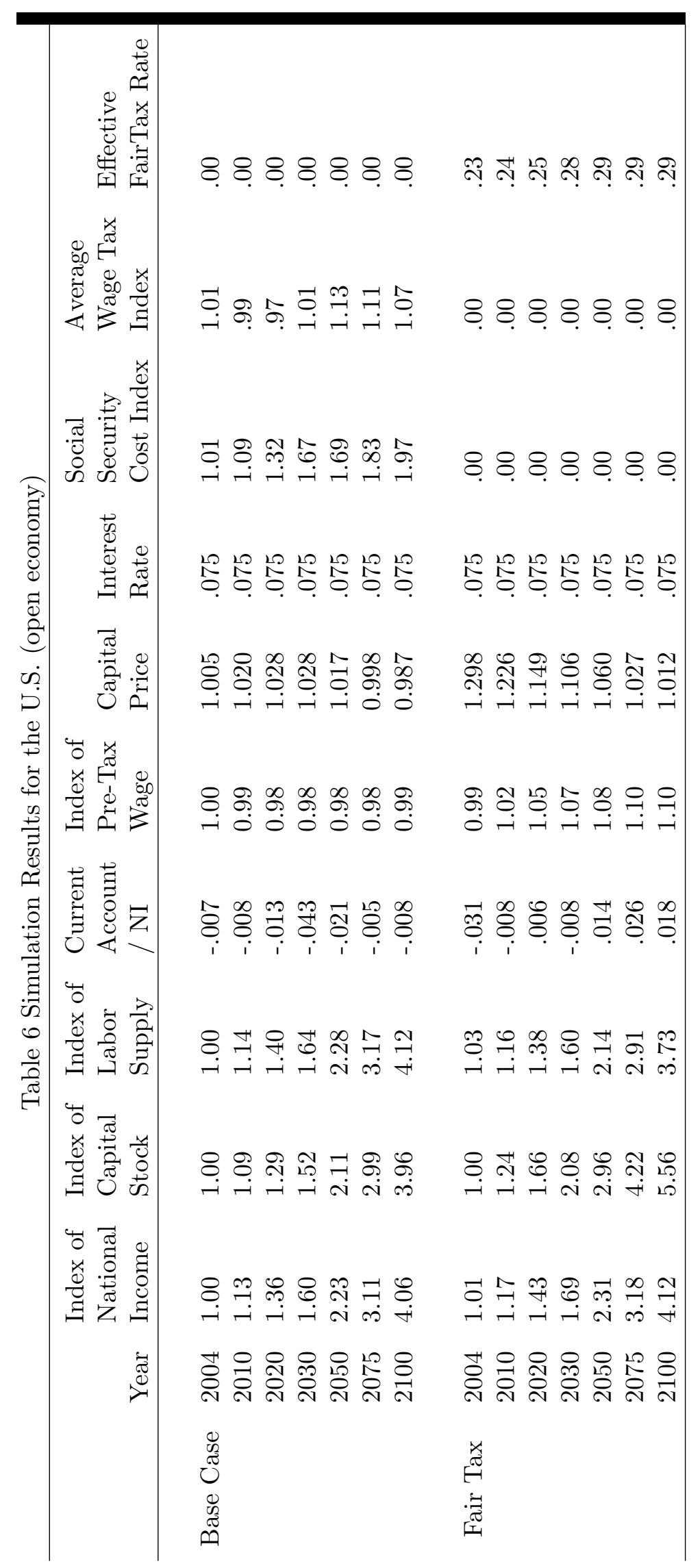


Table 7 Welfare Effects (open economy)

\begin{tabular}{l|rrr}
\hline Birth & \multicolumn{3}{|c}{ Income Class } \\
Year & 1 & 2 & 3 \\
\hline 1920 & 14.70 & 2.47 & -0.27 \\
1930 & 13.56 & 1.37 & -0.67 \\
1940 & 12.66 & 0.66 & -1.13 \\
1950 & 8.02 & -0.60 & -1.47 \\
1960 & 8.62 & -0.09 & -1.17 \\
1970 & 11.37 & 1.77 & 0.12 \\
1980 & 12.79 & 3.18 & 1.70 \\
1990 & 15.64 & 4.72 & 2.51 \\
2000 & 19.36 & 6.83 & 3.53 \\
2010 & 21.55 & 8.12 & 4.21 \\
2020 & 22.27 & 8.51 & 4.41 \\
2030 & 23.13 & 9.02 & 4.66 \\
\hline
\end{tabular}

